\title{
Minigrafting of Shoots, Roots, Inverted Roots, and Somatic Embryos for Rescue of in vitro Citrus Regenerants
}

\author{
Fabio De Pasquale, Salvatore Giuffrida, and Francesco Carimi \\ Centro di Studio Per il Miglioramento Genetico degli Agrumi, Consiglio Nazionale delle Ricerche, c/o \\ Facoltà di Agraria, Viale delle Scienze 11, I-90128 Palermo Italy
}

\begin{abstract}
AdDITIONAL INDEX wORDs. leaf area, micropropagation, Citrus aurantium, Citrus sinensis, Citrus limon, Citrus deliciosa
Abstract. Minigrafting was used for rescue of tissue culture regenerants of the following four species of Citrus: sour orange (C. aurantium L. 'AA CNR 31'), sweet orange [C. sinensis (L.) Osb. 'Valencia Late'], lemon [C. limon (L.) Burm. 'Femminello Comune'] and mandarin ( $C$. deliciosa Tenore 'Tardivo di Ciaculli'). The grafting was carried out with different scion types including shoots, roots, inverted roots and somatic embryos. This material was obtained in vitro from embryogenic stylederived callus. Seedlings of open-pollinated sour orange (C. aurantium L.), Cleopatra mandarin $(C$. reshni Hort. ex Tan.) and 'Troyer' citrange [C. sinensis Osb. x Poncirus trifoliata (L.) Raf.] were used as rootstocks. Minigrafting of shoots, roots, inverted roots and embryos regenerated in vitro allowed successful rescue of these four species. Percentages of successful minigrafts ranged from $100 \%$ (shoots) to $2.5 \%$ (inverted roots). The probability of successful graft unions increased with the age of the rootstock. The final mean canopy leaf area (120 days after grafting) ranged from $5.2 \mathrm{~cm}^{2}$ ('Tardivo di Ciaculli' mandarin grafted on 6-month-old Cleopatra mandarin) to $157.9 \mathrm{~cm}^{2}$ ('Valencia Late' sweet orange grafted on 18-month-old Cleopatra mandarin). In this work we examined some of the variables which influenced minigrafting and we determined the efficacy of this method for rescue of in vitro regenerants of Citrus. This method is also suggested as a technique to produce a high percentage of viable plants from in vitro regenerants difficult to root.
\end{abstract}

In vitro regenerated woody plantlets are often difficult to adapt to ex vitro conditions (Zimmerman, 1988). Micrografting has been shown to shorten the time required for transfer of in vitro-derived kiwifruit (Actinidia deliciosa C.S. Liang \& A.R. Ferguson) plants to the field (Ke et al., 1993). Micrografting has also shown good utility with Citrus, apple (Malus $\times$ domestica Borkh.), and different Prunus species, and can result in the production of virus-free plants (Hartmann et al., 1990). Micrografting has also been used to rejuvenate mature plants (Huang et al., 1992; Perrin et al., 1994; Pliego-Alfaro and Murashige, 1987). Ollitrault (1992) grafted somatic embryos of Citrus on 1-year-old C. volkameriana Ten. \& Pasq. seedlings.

Several Citrus cultivars, which were selected for fruit qualities, do not have a good root system in terms of growth rate, disease resistance, soil adaptation, etc. Grafting may allow in vitro regenerated plantlets of lemon, sweet orange and mandarin susceptible to root diseases to grow normally.

The ability of Citrus tissue culture regenerants to grow on different rootstocks was investigated using a technique based on the existence of in vitro and in vivo micrografting methods for Citrus (Edriss and Burger, 1984; Murashige et al., 1972; Navarro et al., 1975; Tusa et al., 1988).

The aim of the experiments was to test the influence of rootstock and of scion genotype and scion type on the grafting and vegetative growth of tissue culture regenerants of four Citrus species.

\section{Materials and Methods}

RoOTSTOCK PREPARATION. All the plant material used in this study was obtained from the collection of the Centro di Studio per

\footnotetext{
Received for publication 2 Feb. 1998. Accepted for publication 29 Oct. 1998. We would like to thank Francesco Giulio Crescimanno, Istituto di Coltivazioni Arboree, and Lisa Oddo, Dipartimento di Scienze Botaniche, Università degli Studi di Palermo, for helpful discussion, comments and critical reading of the manuscript. This research was supported by Mi. P.A. (Prodotti e tecnologie innovative su piante ornamentali publication 39). The cost of publishing this paper was defrayed in part by the payment of page charges. Under postal regulations, this paper therefore must be hereby marked advertisement solely to indicate this fact.
}

il Miglioramento Genetico degli Agrumi of Palermo. Seeds from sour orange (C. aurantium L. 'AA CNR 33'), Cleopatra mandarin (C. reshni Hort. ex Tan.), and 'Troyer' citrange [C. sinensis Osb. $x$ Poncirus trifoliata (L.) Raf.] were used to provide rootstocks. Because of their high polyembryony, the seedlings produced are principally clonal. Seedlings were also selected on the basis of visual comparison for uniformity, and the off-type seedlings were eliminated.

Seeds were pregerminated as follows: entire fruits were surface-sterilized by immersion for $5 \mathrm{~min}$ in $70 \%$ ethanol and $15 \mathrm{~min}$ in $2 \%(\mathrm{w} / \mathrm{v})$ sodium hypochlorite. About 15 peeled seeds were germinated in petri dishes $(100 \times 15 \mathrm{~mm})$ containing $25 \mathrm{~mL}$ of Murashige and Skoog (1962) (MS) solidified medium $\left(8 \mathrm{~g} \cdot \mathrm{L}^{-1}\right.$ agar type M Sigma A-4800). The $\mathrm{pH}$ was adjusted to $5.7 \pm 0.1$ with 0.5 M potassium hydroxide before autoclaving at $121{ }^{\circ} \mathrm{C}$ for $15 \mathrm{~min}$.

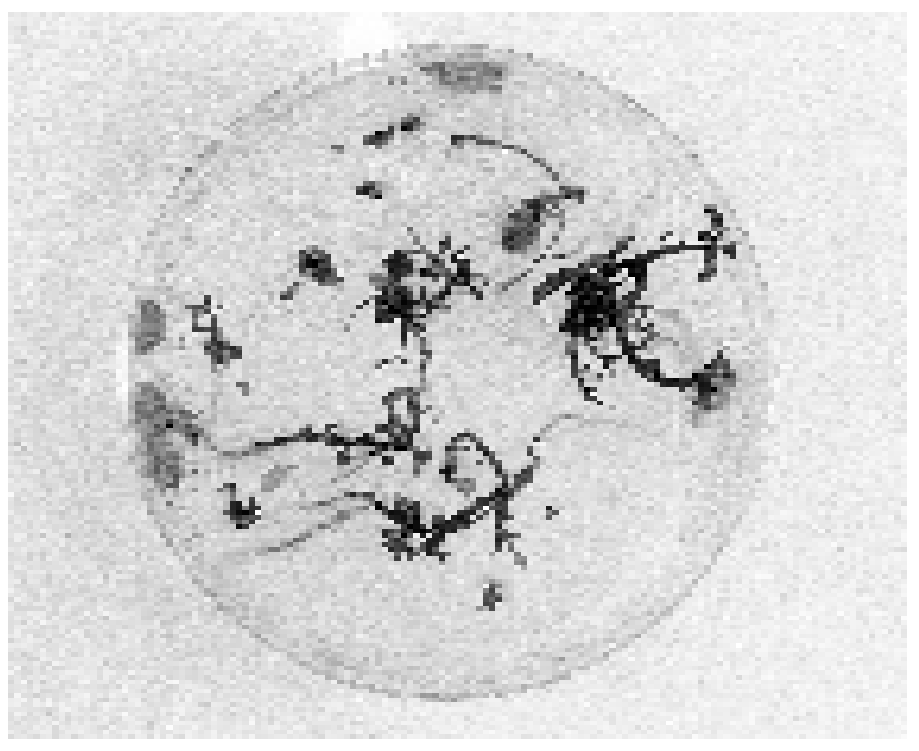

Fig. 1. In vitro regenerants of lemon in petri dishes with fungal contamination. 


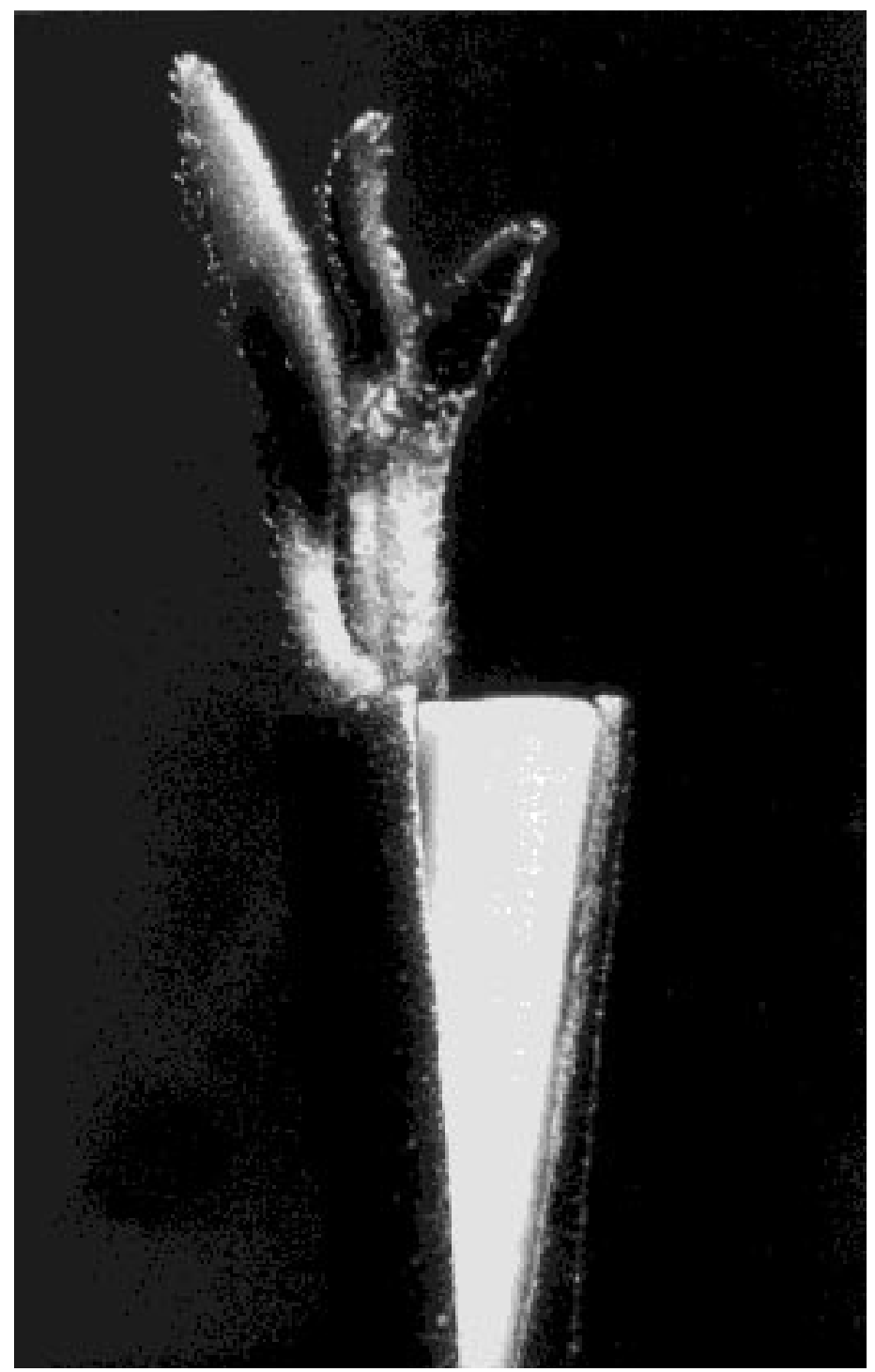

Fig. 2. The scion is inserted into the stock (on the opposite side of the vertical cut) so that the cambium regions match.

Petri dishes were sealed with Parafilm M and maintained at $25 \pm$ $1^{\circ} \mathrm{C}$. After germination, plants were individually transplanted into $7 \times 7 \times 10$-cm plastic pots containing equal parts of peatmoss and sand. The rootstocks used were either 6- or 18-month-old seedlings; in the case of 'Troyer' citrange, only 6-month-old seedlings were used.

For embryo, root and inverted root minigrafting only 'Troyer' citrange was employed as rootstock; in this case shoots originated from the rootstock are identifiable by their trifoliate leaves, and can be easily removed as they emerge.

For the production of 18 months old seedlings, $\approx 6$ months after sowing, plantlets were transferred to $10 \times 10 \times 12 \mathrm{~cm}$ pots containing equal parts of peatmoss and sand. The seedlings were maintained under standard greenhouse conditions $\left(22 / 27^{\circ} \mathrm{C}\right.$ night/ day and natural daylight conditions). A normal strength Hoagland nutrient solution was added at $30-\mathrm{d}$ intervals, and plantlets were irrigated when necessary.

Scion Preparation. Scions were collected from in vitro cultures of stigmas and styles of four different species: sour orange $(C$. aurantium L. 'AA CNR 31'), sweet orange [C. sinensis (L.) Osb. 'Valencia Late'], lemon [C. limon (L.) Burm. 'Femminello
Comune'], and mandarin (C. deliciosa Tenore 'Tardivo di Ciaculli'). The following scions were used: shoots (length 5 to $10 \mathrm{~mm}$ ), roots (length 5 to $10 \mathrm{~mm}$ ), inverted roots (length 5 to $10 \mathrm{~mm}$, the root segment was inverted and then inserted into the graft), and somatic embryos (length 2 to $5 \mathrm{~mm}$ ), all obtained from embryogenic callus derived from style and stigma culture. Plants were regenerated from friable embryogenic calli initiated from styles and stigmas according to Carimi et al. (1995).

A separate experiment was conducted to investigate the possibility of rescue of shoots collected from cultures contaminated with Aspergillus niger van Tieghem (Fig. 1); 40 shoots of lemon were grafted on 6-month-old seedling of sour orange.

GrafTING METHOD AND CARE OF GRAFTS. Before grafting, the rootstocks were decapitated at 7 and $12 \mathrm{~cm}$ for 6- and 18-monthold seedlings respectively. The bark was slit vertically to $5 \mathrm{~mm}$ from the cut surface and lifted slightly along both sides of the cut along the entire circumference (along cambium between bark and wood). Only the rootstocks with the bark slipping (with cambium cells actively dividing) were selected for the grafting (Hartmann et al., 1990).

Before grafting, shoot, root and inverted root were cut diagonally with a single stroke of a razor blade, to remove bark from one side and leave a smooth surface. Somatic embryos were cut vertically under a binocular microscope into two halves, and one half was used as scion. To avoid dehydration of scions during excision and grafting, they were transferred to petri dishes containing sterile distilled water. Only one scion was inserted into each stub. The scions were pushed downward between the bark and the wood of the stock on the opposite side of the vertical cut (Fig. 2). The cambial regions of freshly cut scion tissue was brought in contact with freshly cut rootstock tissue.

The graft union region was wrapped with Parafilm M, so that the parts (held together tightly) would not move about and dislodge the interlocking callus tissue (parenchyma cells) from both stock and scion. The self-sealing Parafilm was closed off with light finger pressure around the graft union region. The entire grafted plants were individually inserted into a polyethylene bag containing $5 \mathrm{~mL}$ of distilled water, sealed with adhesive tape and incubated for 2 months in a climate chamber at $27 \pm 1{ }^{\circ} \mathrm{C}$, under a photosynthetic photon flux of $100 \mu \mathrm{mol} \cdot \mathrm{m}^{-2} \cdot \mathrm{s}^{-1}$ provided by Osram cool-white 18-W fluorescent lamps. About $20 \mathrm{~d}$ after embryo grafting, the Parafilm was cut off with a razor blade to allow the growth of the scion. The grafted plants were observed periodically, and adventitious and axillary shoots from rootstocks were removed as they emerged. Sixty days after grafting, the grafted plants were transferred to the greenhouse and exposed to natural daylight conditions at $22 / 27^{\circ} \mathrm{C}$, night/day. Holes of increasing size were made in the polyethylene bags to reduce humidity levels gradually as described by Gmitter and Moore (1986); $\approx 4$ weeks later the polyethylene bags were removed. Grafted plants were fertilized once a month with Hoagland's solution, and irrigated with distilled water when necessary. To prevent diseases and pests, insecticides (Methomyl, methyl O-(methylcarbamoyl) thiolacetohydroxamate) and fungicides (Fosetyl Al, phosphonic acid monoethyl ester aluminum salt) were applied at 30-d intervals.

ESTIMATION OF LEAF AREA USING LINEAR LEAF MEASUREMENTS. Several, nondestructive methods for measuring the leaf area through linear measurements have been reported by many authors for Citrus (Ascenso and Soost, 1976; Turrel, 1961) and other species (Ajayi, 1990; Hughes and Proctor, 1981; Nautiyal et al., 1990; Oliveira and Santos, 1995; Robbins and Pharr, 1987; Sepulveda and Kliewer, 1983). Criteria for the selection of a regression equation were the coefficients of determination $\left(r^{2}\right)$, the standard 


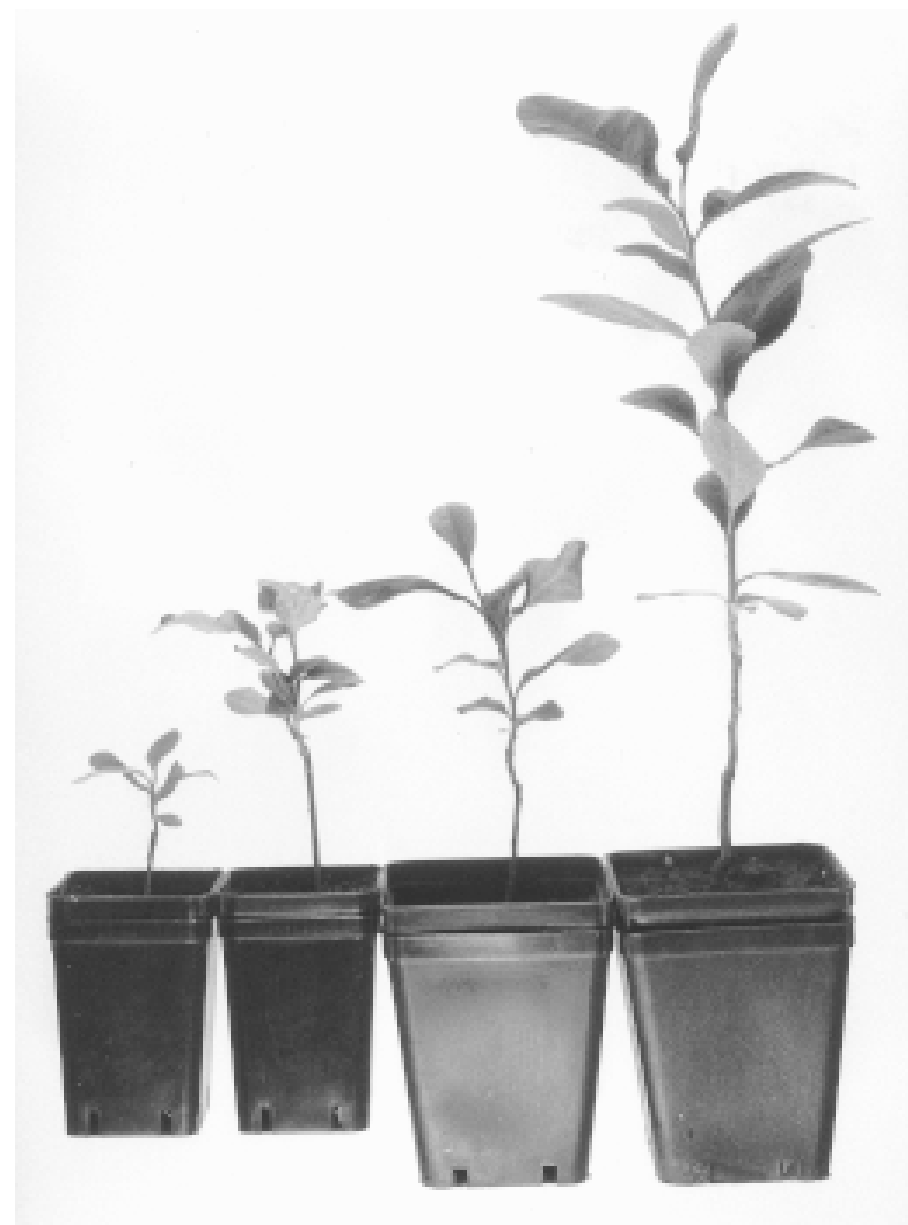

Fig. 3. Grafted plants of lemon 60 and $120 \mathrm{~d}$ after grafting from shoots grafted on 6-month-old (two plants on the left) and 18-month-old (two plants on the right) Cleopatra mandarin.

errors of estimates, the F test of analysis of variance and the significance of the regression coefficients (SPSS-X, Inc., Chicago), as suggested by other authors (Oliveira and Santos, 1995).

We found that the following leaf area estimation equations had the relative advantage of simplicity of calculation and the lowest standard error of estimates, therefore they were chosen.

Sour Orange: $\mathrm{LA}=0.567+0.624(\mathrm{~L} \times \mathrm{W}), r^{2} 0.991$

Sweet Orange: $\mathrm{LA}=0.768+0.604(\mathrm{~L} \times \mathrm{W}), r^{2} 0.921$

Lemon: $\mathrm{LA}=0.226+0.691(\mathrm{~L} \times \mathrm{W}), r^{2} 0.974$

Mandarin: $\mathrm{LA}=0.603+0.637(\mathrm{~L} \times \mathrm{W}), r^{2} 0.869$

where $\mathrm{L}=$ leaf maximum length, $\mathrm{LA}=$ leaf area, and $\mathrm{W}=$ leaf maximum width.

ExPERIMENTAL DESIGN. The percent of successful minigrafting was scored $120 \mathrm{~d}$ after grafting. Mean percentage values including standard errors were calculated.

Each treatment was applied to 40 plantlets. Experiments used a randomized block design, with four replications. Effects of treatment were tested by analysis of variance $(P<0.01)$ (SPSS-X, Inc.); differences among means were tested by Tukey's HSD range test $(P<$ 0.01) (Steel and Torrie 1980). Before analysis, percentage data were arcsine-square root transformed for homogeneity of variances.

To estimate the whole canopy leaf area with the regression equation selected, the maximum width and length of each leaf produced were measured 60, 90, and $120 \mathrm{~d}$ after grafting (non destructive measurements). In this experiment a randomized block design was used, with four replications. Each replication comprised five grafted plants obtained from sour orange, sweet orange, lemon and mandarin shoots grafted on 6- and 18-month-old seedlings of sour orange, Cleopatra mandarin and 6-month-old seedlings of 'Troyer' citrange. Mean whole canopy leaf area values including standard errors were calculated. The final canopy leaf area (120 d after grafting) was statistically examined by analysis of variance.

\section{Results}

EFFECT OF AGE, TYPE OF ROOTSTOCK, AND GENOTYPE GRAFTED ON SUCCESS OF SHOOT MINIGRAFTS. After 10 to $15 \mathrm{~d}$, the grafted plants formed callus tissue, and union was achieved. The callus was produced on both the rootstock and the scion, filling up the spaces between the two components of the graft, becoming intimately interlocked and providing some mechanical support. If callus did not form, the scion became desiccated $\approx 20$ to 30 d after grafting and decayed without any further development. Sixty days after shoot grafting, the grafted plants were transferred to the greenhouse, where plantlets were maintained for 2 months (Fig. 3).

Table 1 shows the influence of scion genotype, age and type of rootstock on the percentage of successful shoot minigrafts. The analysis of variance showed that the percentages of successful shoot minigrafts were significantly affected $(P<0.01)$ by the genotype grafted, the age and the type of rootstock.

A high percentage of grafts was successful, with a strong union and the tissues joined normally. The percentages of successful shoot minigrafts ranged from $27.5 \%$ ('Tardivo di Ciaculli' mandarin grafted on 6-month-old Cleopatra mandarin) to $100.0 \%$ ('AA CNR 31' sour orange grafted on 18-month-old sour orange, and 'Femminello Comune' lemon grafted on 18-month-old sour orange and 18-month-old Cleopatra mandarin) (Table 1).

'Tardivo di Ciaculli' mandarin showed the lowest successful percentage, $63 \%$, whereas the higher percentage, $96 \%$, was observed with 'Femminello Comune' lemon (Table 1). Sour orange rootstocks produced higher percentages of successful minigrafts than Cleopatra mandarin.

Table 1. Influence of age, type of rootstock, and genotype grafted on percent of successful shoot minigrafting. Each percentage comprised 40 samples.

\begin{tabular}{|c|c|c|c|c|c|}
\hline \multirow[b]{3}{*}{ Scion } & \multicolumn{4}{|c|}{ Rootstock age (months) } & \multirow[b]{3}{*}{ Avg } \\
\hline & 6 & 18 & 6 & 18 & \\
\hline & \multicolumn{2}{|c|}{ Sour orange } & \multicolumn{2}{|c|}{ Cleopatra mandarin } & \\
\hline Sour orange & $87.5 \mathrm{CD}^{\mathrm{z}}$ & $100.0 \mathrm{~A}$ & $85.0 \mathrm{D}$ & $95.0 \mathrm{ABC}$ & 91.9 \\
\hline Sweet orange & $90.0 \mathrm{BCD}$ & $97.5 \mathrm{AB}$ & $70.0 \mathrm{E}$ & $67.5 \mathrm{E}$ & 81.3 \\
\hline Lemon & $95.0 \mathrm{ABC}$ & $100.0 \mathrm{~A}$ & $90.0 \mathrm{BCD}$ & $100.0 \mathrm{~A}$ & 96.3 \\
\hline Mandarin & $52.5 \mathrm{~F}$ & 87.5 CD & $27.5 \mathrm{G}$ & $85.0 \mathrm{D}$ & 63.1 \\
\hline Average & 81.3 & 96.3 & 68.1 & 86.9 & \\
\hline
\end{tabular}

${ }^{\mathrm{z} D i f f e r e n t ~ c a p i t a l ~ l e t t e r s ~ d e n o t e ~ s i g n i f i c a n t ~ d i f f e r e n c e s ~}(P<0.01)$ throughout columns (Tukey's HSD range test). 
Table 2. Influence of genotype and type of scion grafted on percent of successful minigrafting. Each percentage comprised 40 scions grafted on 6month-old seedlings of 'Troyer' citrange.

\begin{tabular}{llccc}
\hline \hline $\begin{array}{l}\text { Scion } \\
\text { species }\end{array}$ & Roots & $\begin{array}{c}\text { Inverted } \\
\text { roots }\end{array}$ & Embryos & Shoots \\
\hline Sour orange & $35.0 \mathrm{DE}^{\mathrm{z}}$ & $7.5 \mathrm{IL}$ & $25.0 \mathrm{~F}$ & $87.5 \mathrm{AB}$ \\
Sweet orange & $22.5 \mathrm{~F}$ & $5.0 \mathrm{IL}$ & $15.0 \mathrm{GH}$ & $92.5 \mathrm{~A}$ \\
Lemon & $40.0 \mathrm{D}$ & $15.0 \mathrm{GH}$ & $32.5 \mathrm{E}$ & $82.5 \mathrm{~B}$ \\
Mandarin & $20.0 \mathrm{FG}$ & $2.5 \mathrm{~L}$ & $10.0 \mathrm{HI}$ & 33.8 \\
Average & 29.4 & 7.5 & 20.6 & $46.5 \mathrm{C}$ \\
\end{tabular}

${ }^{\mathrm{z} D i f f e r e n t ~ c a p i t a l ~ l e t t e r s ~ d e n o t e ~ s i g n i f i c a n t ~ d i f f e r e n c e s ~}(P<0.01)$ throughout columns (Tukey's HSD range test).

The probability of successful graft unions increased with the age of the rootstock. When the rootstock was 6 months old, $81.3 \%$ and $68.1 \%$ of the graft unions were successful compared to $96.3 \%$ and $86.9 \%$ when the rootstock was 18 months old (respectively on sour orange and Cleopatra mandarin) (Table 1). After 2 years the viable grafts never showed symptoms of incompatibility.

No significant differences in the percentage of grafting success (shoots of lemon grafted on 6-month-old sour orange) resulted between scions collected from petri dishes with fungal contamination and petri dishes without contamination.

EFFECT OF SCION GENOTYPE AND SCION TYPE ON MINIGRAFTS. In this experiment different types of scion were tested for their effect on successful minigrafting percentages. It was possible to obtain viable grafted plants when shoots, roots, inverted roots and em-

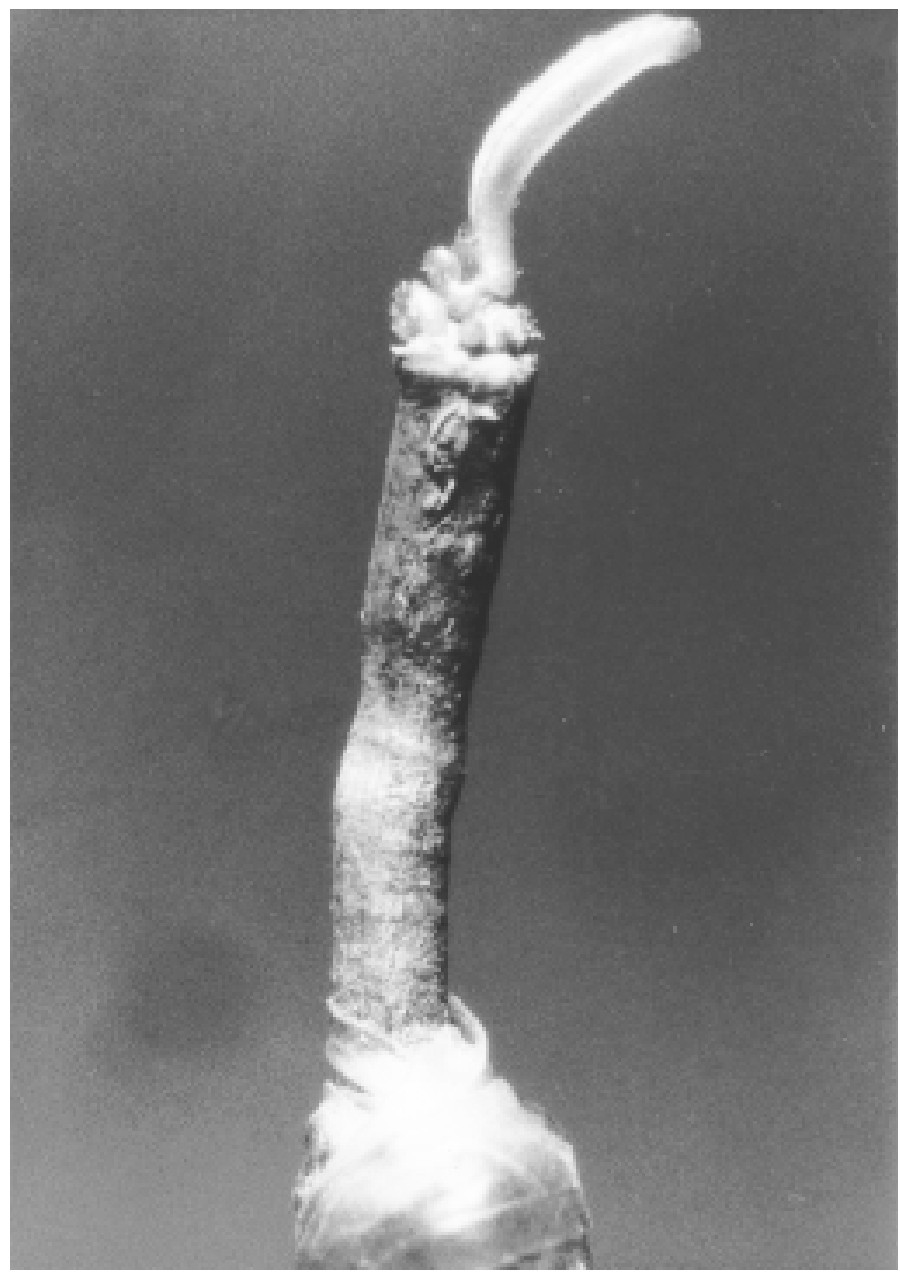

Fig. 4. Adventitious shoots of lemon arising from the cut surface of a lemon root grafted on 'Troyer' citrange. bryos were grafted on 6-month-old seedlings of 'Troyer' citrange.

Table 2 shows the percentages of successful minigrafting of different genotypes and types of scion grafted on 'Troyer' citrange. The analysis of variance showed that the percentages of successful minigrafting were significantly affected $(P<0.01)$ by the genotype and by the types of scion grafted. The percentages of successful minigrafts ranged from $2.5 \%$ (inverted roots of 'Tardivo di Ciaculli' mandarin) to $92.5 \%$ (shoots of 'Valencia Late' sweet orange). 'Tardivo di Ciaculli' mandarin showed the lowest successful percentage, $19.8 \%$, whereas the highest percentage, $42.5 \%$, was observed with 'Femminello Comune' lemon (Table 2).

Differences in successful minigrafting percentages between the different types of scion used were observed. Maximum percentage of successful minigrafting, $77.3 \%$, could be achieved when shoots

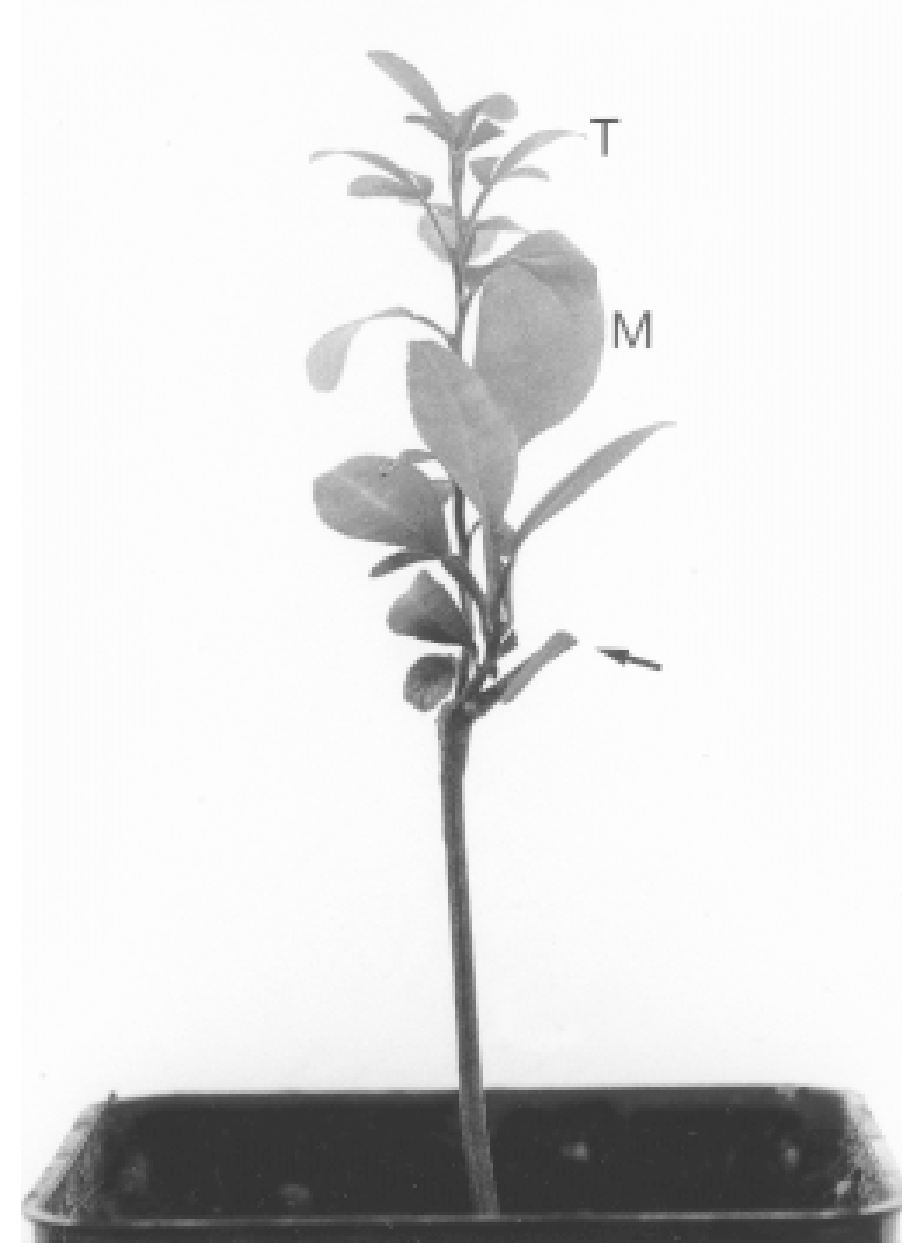

Fig. 5. Inverted root minigrafting of lemon. Note the development of an adventitious root (arrow) arising from the distal end of the inverted root grafted on 'Troyer' citrange and the monolobate lemon $(\mathrm{M})$ and trilobate 'Troyer' citrange $(\mathrm{T})$ leaves. 
were grafted, whereas the lowest average percentage, $7.5 \%$, was observed when inverted roots were used as scion (Table 2).

When root minigrafts were successful, at least one or several adventitious shoots emerged from the top of the root (Fig. 4), but usually only one survived and developed. Most of the inverted root minigrafts failed, but when they were successful the new vegetation arose from the portion of the inverted root inserted between the bark and the wood of the rootstock. Figure 5 shows an inverted lemon root grafted on 'Troyer' citrange; it is possible to distinguish the trilobate leaves $(\mathrm{T})$ of the rootstock and the monolobate leaves (M) of the scion. In two cases, the grafting of inverted roots of lemon induced the formation of an adventitious root (arrow in Fig. 5) from the distal end of the inverted root grafted.

When roots and embryos were grafted the percentages of successful minigrafting obtained were $29.4 \%$ and $20.6 \%$ respectively (Table 2). When embryos were grafted, they generally produced very soft vegetation unable to expand through the Parafilm. In these cases, $20 \mathrm{~d}$ after grafting, it was necessary to remove the Parafilm with a scalpel.

EFFECT OF AGE AND SPECIES OF ROOTSTOCK ON LEAF AREA. Figure 6 shows the whole canopy leaf area of the shoots of the different genotypes grafted on different rootstock 60, 90, and $120 \mathrm{~d}$ after grafting.

The analysis of variance showed that the final canopy leaf area (120 d after grafting) was significantly affected $(P<0.01)$ by the age and by the type of rootstock used. The final mean canopy leaf area ranged from $5.2 \mathrm{~cm}^{2}$ ('Tardivo di Ciaculli' mandarin grafted on 6-month-old Cleopatra mandarin, Fig. 6D) to $157.9 \mathrm{~cm}^{2}$ ('Valencia Late' sweet orange grafted on 18-month-old Cleopatra mandarin, Fig. 6B). The highest final canopy leaf area was obtained when shoots were grafted on 18-month-old Cleopatra mandarin, with the exception of lemon which developed the highest final canopy leaf area when grafted on 18-month-old sour orange (Fig. 6C).

\section{Discussion}

In this work we examined some of the variables which influenced minigrafting and we determined the efficacy of this method for rescue of in vitro regenerants of four Citrus species. In vivo minigrafting of Citrus is suggested as a technique to produce a high percentage of viable plants from in vitro regenerants that are difficult to root.

Grafting for rescue of uncontaminated and contaminated in vitro regenerants of Citrus can be performed in vivo, so as to recover contaminated material. Grafting in the former instance can be done with shoots, embryos, roots and inverted roots. In the case when in vitro regenerated plantlets produce a poorly developed stem, the roots can be useful for plant rescue, increasing the grafting materials. In the roots segments used for grafting it is not possible to distinguish the polarity after the cut. Since inverted root grafts have a much lower success rate, care must be taken to maintain the right polarity when roots are used as scion.

In the few cases of successful union of the inverted root scion, the root polarity was maintained: the new shoots were formed from the lower part, while the roots emerged from the higher part of the root portion grafted. The effects of gravity seems to play a minor role in the root's developmental program.

For embryo and inverted root minigrafting, it is important to use a rootstock with a distinct morphological marker (trifoliate leaves) that clearly distinguishes the rootstock from the scion (Murashige et al., 1972). In this case, the rootstock shoots can be easily removed as they emerge. The minigrafting protocol described permits grafting year-round.

The grafting success rate depended upon the age of the rootstock, the species grafted and the type of scion. It also depended upon the growth activity of the stock plant (bark slipping). Preliminary experiments showed that only the rootstocks with cambium cells that separated easily from one another gave satisfactory results. When the rootstock plant is physiologically less active it is sufficient to transfer the plant into a climate chamber at $27 \pm 1{ }^{\circ} \mathrm{C}$ and $95 \%$ to $100 \%$ relative humidity for 20 to $30 \mathrm{~d}$; after this treatment the rootstock bark "slips" and it is possible to graft it.

The grafting behavior of the different species of Citrus observed in this study is comparable with the behavior of the different species in conventional grafting. In fact, the highest percentage of successful grafts was obtained when lemon was used as scion, while the lowest was achieved with mandarin. Mandarin seems much more difficult to graft than the other species; nevertheless, once successfully grafted, mandarin grows very well with a good graft union. The frequency of successful minigrafting obtained in this study is lower than that observed by Ollitrault (1992) $(60 \%$ success for embryo grafting), while it is higher compared with other previously mentioned cases of micrografting (Edriss and Burger, 1984; Murashige et al., 1972; Tusa et al., 1988).

The new callus tissue produced from the cambial region is very sensitive to dehydration, therefore it is important for the produc-

Fig. 6. Whole canopy leaf area of (A) sour orange, (B) sweet orange, (C) lemon, and (D) mandarin shoots grafted on 6- and 18-month-old seedlings of sour orange (SO), Cleopatra mandarin (CM), and 6-month-old seedlings of 'Troyer' citrange (CIT), 60, 90, and 120 d after grafting. Vertical bars denote SE of mean. Each average comprised 20 sample plants.

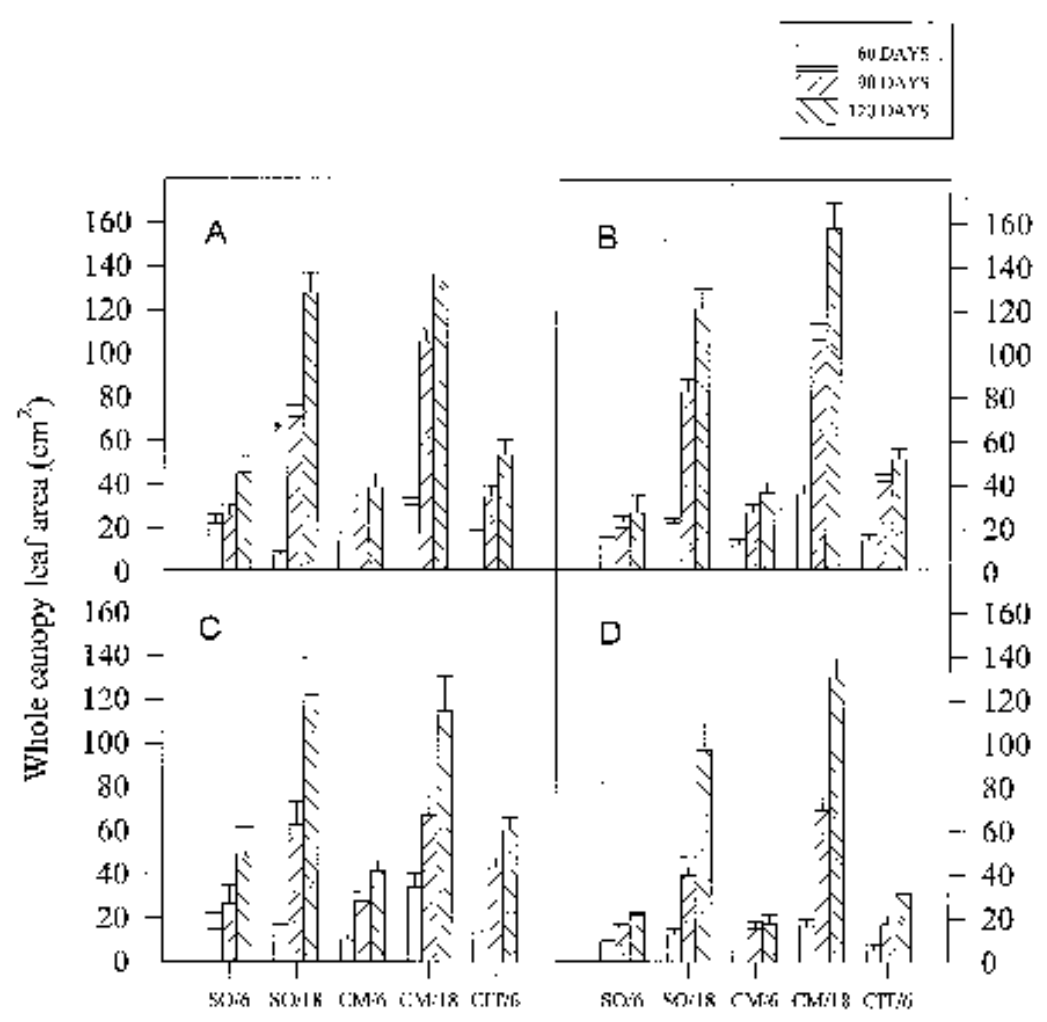

Roytstock species inge (months) 
tion of these cells that the air moisture around the graft union is kept at high levels. This is the reason why sealing the graft union with Parafilm and placing the grafted plants under high relative humidity conditions was effective in preventing the loss of moisture and the death of the tender, exposed cells of the cut surfaces (of the stock and scion) and of the new callus tissue produced. High humidity conditions also prevented dehydration of the tender scions. Parafilm $\mathrm{M}$ is flexible enough to allow the growth of the small scions and of the soft-barked seedlings without constriction. Beineke (1978) reported that Parafilm was used in place of paraffin on black walnut (Juglans nigra L.) grafts.

\section{Literature Cited}

Ajayi, N.O. 1990. Rapid determination of leaf area in ovate vegetable leaves by linear measurements. J. Hort. Sci. 65:1-5.

Ascenso, J.C. and R.K. Soost. 1976. Relationships between leaf surface area and linear dimension in seedling Citrus populations. J. Amer. Soc. Hort. Sci. 101:696-698.

Beineke, W.F. 1978. Parafilm: A new way to wrap grafts. HortScience 13:284.

Carimi, F., F. De Pasquale, and F.G. Crescimanno. 1995. Somatic embryogenesis in Citrus from styles culture. Plant Sci. 105:81-86.

Edriss, M.H. and D.W. Burger. 1984. Micro-grafting shoot-tip culture of Citrus on three trifoliolate rootstocks. Scientia Hort. 23:255-259.

Gmitter, F.G. and G.A. Moore. 1986. Plant regeneration from undeveloped ovules and embryogenic calli of Citrus: Embryo production, germination, and plant survival. Plant Cell Tiss. Org. Cult. 6:139-147.

Hartmann, H.T., D.E. Kester, and F.T. Davies, Jr. 1990. Plant propagation: Principles and practices. 5th ed. Prentice Hall, Englewood Cliffs, N.J.

Huang, L.C., S. Lius, B.L. Huang, T. Murashige, E.F.M. Mahdi, and R. Van Gundy. 1992. Rejuvenation of Sequoia sempervirens by repeated grafting of shoot tips onto juvenile rootstocks in vitro. Plant Physiol. 98:166-173.

Hughes, B.R. and J.T.A. Proctor. 1981. Estimation of leaflet, leaf and total leaf area of Panax quinquefolius L. using linear measurements. J. Amer. Soc. Hort. Sci. 106:167-170.
Ke, S., Q. Cai, and R.M. Skirvin. 1993. Micrografting speeds growth and fruiting of protoplasts-derived clones of kiwifruit (Actinidia deliciosa). J. Hort. Sci. 68:837-840.

Murashige, T., and F. Skoog. 1962. A revised medium for rapid growth and bioassays with tobacco tissue cultures. Physiol. Plant. 15:473-497.

Murashige, T., W.P. Bitters, T.S. Rangan, E.M. Nauer, C.N. Roistacher, and P.B. Holliday. 1972. A technique of shoot apex grafting and its utilization towards recovering virus-free Citrus clones. HortScience 7:118-119.

Nautiyal, M.C., P.K. Singh, R.N. Shukla, S. Prakash, and A. Kumar. 1990. Correcting leaf area measurement by conventional methods: A new approach for apple (Malus domestica Borkh). J. Hort. Sci. 65:15-18.

Navarro, L., C.N. Roistacher, and T. Murashige. 1975. Improvement of shoot-tip grafting in vitro for virus-free Citrus. J. Amer. Soc. Hort. Sci. 100:471-479.

Oliveira, M. and M. Santos. 1995. A semi-empirical method to estimate canopy leaf area of vineyards. Amer. J. Enol. Viticult. 46:389-391.

Ollitrault, P. 1992. Somatic embryo grafting: A promising technique for citrus breeding and propagation. Fruit 47:213-218.

Perrin, Y., L. Lardet, F. Enjalric, and M.P. Carron. 1994. Rajeunissement de clones matures d'Hevea brasiliensis (Müll. Arg.) par microgreffage in vitro. Can. J. Plant. Sci. 74:623-630.

Pliego-Alfaro, F. and T. Murashige. 1987. Possible rejuvenation of adult avocado by graftage onto juvenile rootstocks in vitro. HortScience 22:1321-1324.

Robbins, N.S. and D.M. Pharr. 1987. Leaf area prediction models for cucumber from linear measurements. HortScience 22:1264-1266.

Sepulveda, G.R. and W.M. Kliewer. 1983. Estimation of leaf area of two grapevine cultivars (Vitis vinifera L.) using laminae linear measurements and fresh weight. Amer. J. Enol. Viticult. 34:221-226.

Steel, R.D.G. and J.H. Torrie. 1980. Principles and procedures of statistics. 2nd ed. McGraw-Hill, New York.

Turrel, F.M. 1961. Growth of the photosynthetic area of Citrus. Bot. Gaz. 122:284-298.

Tusa, N., L. Radogna, M. Davino, and R. La Rosa. 1988. Micrografting technology for recovering three virus/affected 'Femminello' lemon clones. Acta Hort. 227:104-106.

Zimmerman, R.H. 1988. Micropropagation of woody plants: Post tissue culture aspects. Acta Hort. 227:489-499. 